\title{
Challenges, Strategies, and Recommendations for the Huge Surge in Plastic and Medical Waste during the Global COVID-19 Pandemic with Circular Economy Approach
}

\author{
Targol Teymourian $^{1} \cdot$ Termeh Teymoorian $^{2} \cdot$ Elaheh Kowsari $^{2} \cdot$ Seeram Ramakrishna $^{3}$ \\ Received: 26 January 2021 / Revised: 1 March 2021 / Accepted: 2 March 2021 / Published online: 2 April 2021 \\ (C) The Author(s), under exclusive licence to Springer Nature Singapore Pte Ltd. 2021
}

\begin{abstract}
After December 2019, the globe was affected by a new coronavirus (SARS-CoV-2) that causes severe respiratory illnesses, which is responsible for increasing environmental problem consequences related to the extra consumption of medical waste and single-use plastics (such as personal protective equipment (PPE) and packaging plastics). Although the consumption of these plastics protects our life during this crisis, it is pivotal to move toward plastic recycling processes and environmentally friendly and sustainable alternatives, like bio-based degradable plastics with a circular economy perspective. This review article collected scattered information and provided a future perspective on how worldwide COVID-19 disruption can perform as a catalyst to improve plastic and medical waste management. Additionally, this paper illustrates the most effective disinfection technologies for COVID-19 wastes, such as high/low heat technologies and chemical disinfection, and PPE reusing processes, including dry heat, vaporized hydrogen peroxide, ozone, and UV light during the outbreak. In this vein, medical waste treatment facilities must be more automatic, with a minimum of personnel involved. Moreover, some recent valid guidelines from different international organizations and countries, future outlook, and practical recommendations that could be effective during this epidemic or even in the post-pandemic world for plastic and medical waste management were provided. Ultimately, governments should improve their waste management because of the potential of pathogen transmission or increased plastic and medical waste generation and try to enhance the environmental knowledge of society. People also should revise their viewpoints on plastic consumption by elevating sustainable behaviors, abandoning old habits, and adjusting to novel ones.
\end{abstract}

Keywords COVID-19 $\cdot$ Plastic waste $\cdot$ Medical waste $\cdot$ Waste management $\cdot$ Reusing processes

\section{Introduction}

The novel coronavirus (SARS-CoV-2) was identified in Wuhan (China) (Contreras et al. 2020), in late December

Elaheh Kowsari

Kowsarie@aut.ac.ir

Seeram Ramakrishna

seeram@nus.edu.sg

1 Department of Civil and Environmental Engineering, Amirkabir University of Technology (Tehran Polytechnic), Hafez St., Tehran 15875-4413, Iran

2 Department of Chemistry, Amirkabir University of Technology (Tehran Polytechnic), Hafez St., Tehran 15875-4413, Iran

3 Department of Mechanical Engineering, Center for Nanofibers and Nanotechnology, National University of Singapore, 21 Lower Kent Ridge Rd, Singapore 119260, Singapore
2019 (Severo et al. 2020), which is responsible for the severe acute respiratory syndrome that is known as COVID-19 and has affected millions of people all around the world. The severity of coronavirus, combined with high contagiousness, including direct contact with contaminated waste or surfaces, direct human contact, and respiratory or airborne droplets (Anderson et al. 2020; Lewis 2020; Morawska and Cao 2020), has increased fear and attention from the scientific community, medical staff, governments, and the general public to control and prevent its transmission (Dietz et al. 2020; Heller et al. 2020; Kitajima et al. 2020; Silva et al. 2020). In such a crisis, many countries have enforced to order lockdown as a possible protection measure against the global pandemic (Muhammad et al. 2020; Phan et al. 2020). This situation has brought the opportunity for researchers to investigate the impacts of humans on Earth or the environment (Lindsey et al. 2020; Manenti et al. 2020; Rutz et al. 2020; Ryan et al. 2020). It turns out that the lockdown and pandemic have led to 
several positive and negative indirect environmental impacts such as prompt improvements in surface water (Braga et al. 2020; Yunus et al. 2020) and air quality (Jiang et al. 2021; Pakravan-Charvadeh et al. 2020), environment noise reduction, cleaner roads and beaches (Zambrano-Monserrate et al. 2020), reduction in indoor air quality (Dutheil et al. 2020; Faridi et al. 2020), decrease on deforestation (Chakraborty and Maity 2020), increase in incineration or landfilling, the decline in waste recycling (Zambrano-Monserrate et al. 2020), increase in ecological danger to natural ecosystems because of disinfectants usage (Zhang et al. 2020), increase in the use of hazardous chemical substances for disinfection in outdoor environments and household (Chang et al. 2020; Wang et al. 2020a), increase in medical waste (Abu-Qdais et al. 2020; Ding et al. 2020), and increase in plastic waste (Liu and Schauer; Nowakowski et al. 2020; Prata et al. 2020).

In addition, plenty of research about the persistence of coronavirus on different materials and surfaces or decontamination and contamination of inanimate surfaces have been done (Kampf et al. 2020), which shows that coronavirus could persist up to approximately 9 days and could successfully be inactivated by various biocidal products. The persistence also was influenced by climatic and environmental factors such as solar radiation, humidity, and temperature. Coronavirus can remain viable on various surfaces (under laboratory conditions) (Van Doremalen et al. 2020). Additionally, in some research, the stability of coronavirus on the different surfaces was studied in detail. The infectious virus can not be recovered from tissue and printing after $3 \mathrm{~h}$ of incubation, and also from treated cloth and wood on the second day. On the other hand, coronavirus was more stable on the banknote and glass for about 4 days and also can resist 7 days on plastic and stainless steel (Chin et al. 2020). The properties depended on the persistence of the SARS-CoV-2 on different surfaces, bring difficulties and problems for public and environmental health, not only in sanitary waiting rooms, operating theaters, and hospitals but also in museums, cinemas, schools, and even in waste collection and treatment systems.

Under these circumstances, waste management has been affected harshly by the existing extra and infected plastic and medical waste in many countries (Malgorzata et al. 2020; Zambrano-Monserrate et al. 2020). Moreover, unsuitable collection practices and pre-treatment systems or lack of proper knowledge about coronavirus disinfection might lead to pollution of public municipal solid waste (MSW), which might bring a risk of coronavirus transmission (Di Maria et al. 2020a; Kulkarni and Anantharama 2020; Nghiem et al. 2020). Thus, the secure management and ultimate disposal of plastic and medical waste is a crucial element of a suitable emergency response. Hence, devising a proper plan for treating household waste, medical waste, or other hazardous waste could be considered a necessary public service by governments in order to minimize any possibility of secondary impacts on the environment and health (Chauhan et al. 2020; UNEP 2020).
The main purpose of this review is to highlight the global challenges and pressing issues of solid waste management (SWM) regarding plastic and medical waste and presents information about different available policies and methods for treatment during the COVID-19 crisis with a circular economy perspective. Eventually, this paper brings quite a few recommendations from different recent studies that could be useful for SWM during the COVID-19 pandemic or even in the post-pandemic. The graphical framework of this paper is summarized in Fig. 1.

\section{Impact of COVID-19 Pandemic on Waste Generation}

Since the news of person-to-person transmission of the virus has been covered in the media all around the world, there was a prompt change in the quality and quantity of waste generation because of various suppression or mitigation actions being implemented in many countries for coronavirus. This circumstance has led to a sharp increase in medical waste and plastic product use and disposal, even for non-medical usage (Thakur 2020; Van Doremalen et al. 2020). This huge amount of extra wastes, which is increasing sharply, can be separated into three main parts, namely packaging plastics waste, personal protective equipment (PPE) waste, and medical waste (Fig.2 (Klemeš et al. 2020; Vanapalli et al. 2020)). These shifts might worsen environmental issues with solid waste management, which definitely existed even before the pandemic (Behera et al. 2020; Bigdeloo et al. 2021; Di Maria et al. 2020b; Manupati et al. 2020; Thakur et al. 2020; Tirkolaee et al. 2020b; Wang et al. 2020b; Yin et al. 2018).

\section{Packaging Plastics}

During home quarantine and public lockdown, the behavior of consumers alarmingly has changed. This situation has made people panic to buy a huge amount of goods, especially from online grocery stores (Scaraboto et al. 2020; Sharma et al. 2020). Dependency on online shopping during the lockdown in order to use home delivery for essential and commercial products has led to the huge need for single-use plastic bags (Bengali 2020; Sim et al. 2020; Singh et al. 2020b), such as PP, HDPE, PS, and PET (Sharma et al. 2020), which has caused a huge increase in plastic packaging waste production. In addition, paranoia for coronavirus has contributed to irrational and sudden stockpiling of edible products or other groceries by considering the long shelf-life products, which have caused an unwelcome surge of demand for packaging products all around the world. The increased request for plastics is often limited to grocery or food packaging and is consisted of multi-layered plastics, film, and foam which is considered as the subject of profound challenge and concern due to low 

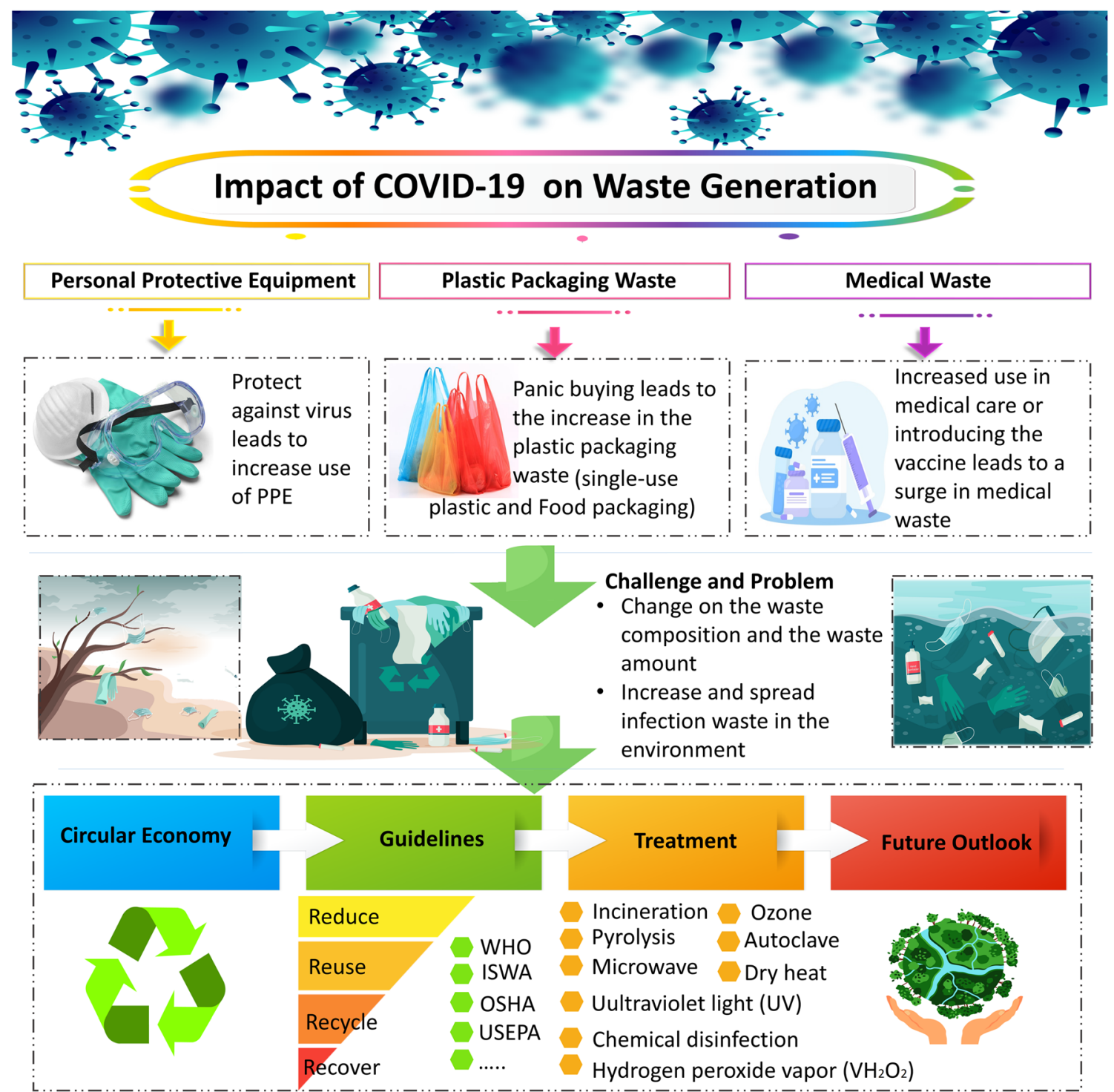

Fig. 1 The graphical framework of challenges, strategies, and recommendations during the pandemic

recyclability properties (Klemeš et al. 2020; Singh 2020; Tenenbaum 2020; Vanapalli et al. 2020).

\section{Personal Protective Equipment}

The geographical spread of the COVID-19 beyond the prime epicenter has increased the demand for widely and efficiently existing medical facilities. It also has been tuned out that the conventional production lines could not fulfill the possible demand during a pandemic. Coronavirus can easily transmit through respiratory droplets or cough, contaminated surfaces, and bodily fluids (Chan et al. 2020; Fadare and Okoffo 2020; Prata et al. 2020). It is vitally important that medical professionals do not be infected by the coronavirus, which guarantees the continuous and safe care of patients and subclinical patients during illness and even after recovery, which means the virus would not be transmitted from person to person. For example, the accessibility of personal protective equipment between health care workers in China had led to little prevalence of the progressing coronavirus within hospitals. On the other hand, due to the lack of ample personal protective equipment in Sweden, approximately $25 \%$ of health care workers were infected (Das et al. 2020). Moreover, in order to limit the pandemic, it is also essential that ordinary citizens remain disease-free. Thus, personal protective equipment such as facemask, gloves, and face shield is essential for the protection of patients, health care personnel, and individuals during the pandemic as well as future viral outbreaks (Prata et al. 2020; Yao et al. 2019).

The World Wildlife Fund (WWF) reported that if only $1 \%$ of the mask wastes are incorrectly dispersed in nature, resulting in approximately 10 million/month masks will pollute the environment (ItalyWWF 2020; Kumar et al. 2020). Moreover, scientists believe that face masks are made from 
Fig. 2 Plastic waste generation by considering different segments and the expected rise in packaging and medical segments

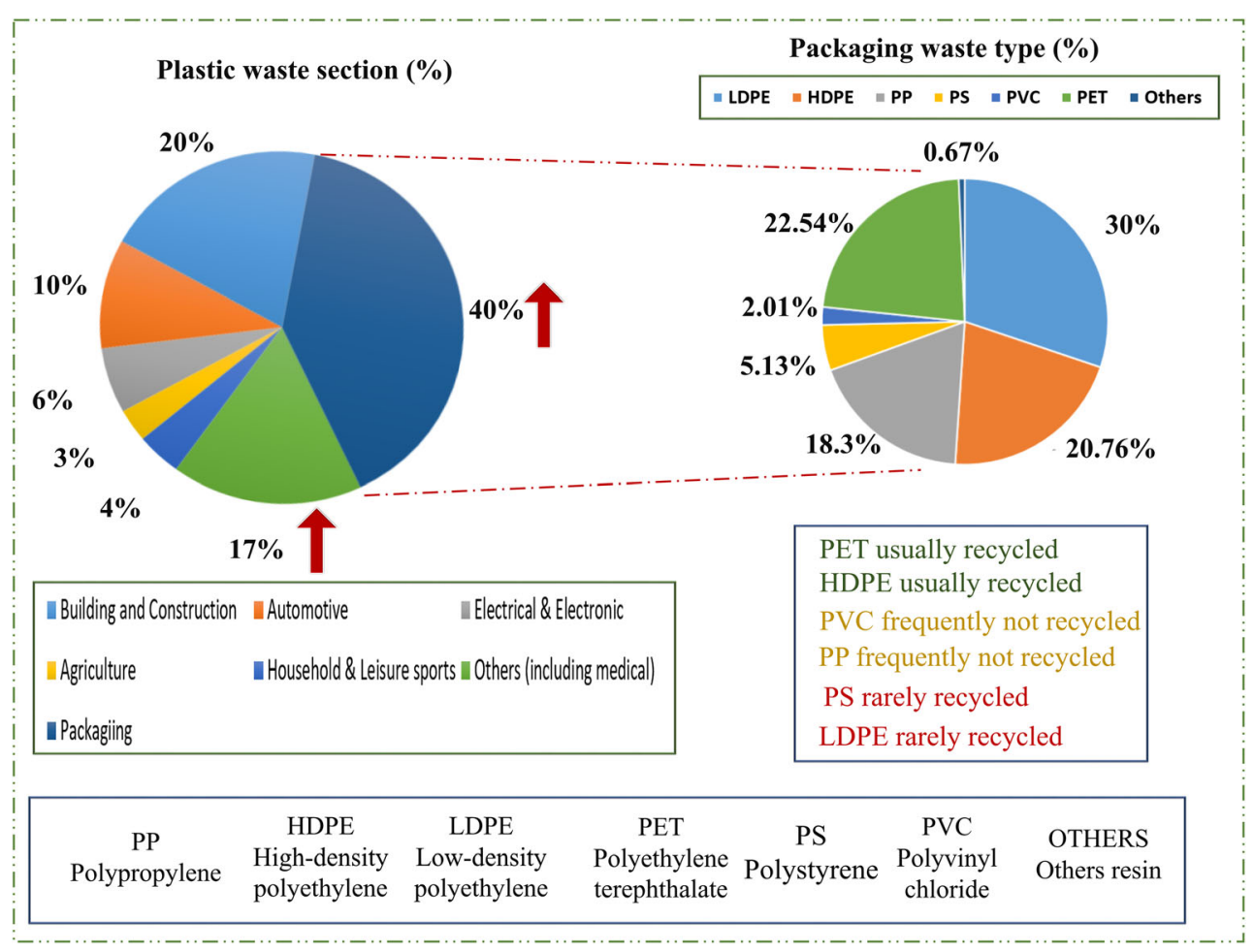

different polymers such as polypropylene in multiple layers, making them harder to recycle (Monella 2020).

\section{Medical Waste}

Since the prevalence of coronavirus, medical waste generation, including white gowns, test kits, plastic containers, and especially syringes after the invention of the COVID-19 vaccine, has been increased all around the world, which is a significant threat to the environment and public health. Collection of the suspected patients, diagnosis and treatment of a large number of patients, and eventually disinfection have led to produce lots of infectious medical wastes, which are mostly made of plastic (Somani et al. 2020; Varbanov et al. 2020; Zambrano-Monserrate et al. 2020). For example, during the disease outbreak, in China, the quantity of MSW in medium and large cities has declined by $30 \%$; however, the medical waste generation with a high ratio of plastics has grown rapidly (approximately 370\%) in Hubei province. Wuhan in China, during the pandemic, generated even more than 240 tons/day of medical wastes (Klemeš et al. 2020; Saadat et al. 2020), which is approximately 190 tons higher than the usual time. In a similar way, Bangkok in Thailand, Manila in the Philippines, Kuala Lumpur in Malaysia, and Hanoi in Vietnam experienced huge increases in producing almost 154-280 tons/day further medical waste during the outbreak than before. Also, in other cities such as Ahmedabad in India, the size of medical waste production risen from 550 to $600 \mathrm{~kg} /$ day to almost $1000 \mathrm{~kg}$ /day during the lockdown (Somani et al.
2020; Zambrano-Monserrate et al. 2020). Under such circumstances, the challenge of the sudden increase in plastic wastes and their infection and environmental pollution has raised global concern (Van Doremalen et al. 2020). Since 2003, after the spread of Severe Acute Respiratory Syndrome (SARS) in the area, more than thirty emergency and legislative management mandates of medical waste have been performed in China. The successful measures in Wuhan and other cities in China achieved from SARS and coronavirus led to manage medical waste and they can be a piece of precious information for other countries especially developing countries that are dealing with a rapid increase in medical waste (Singh et al. 2020b) (Nzediegwu and Chang 2020).

\section{Waste Management during COVID-19 Pandemic}

\section{Challenges and Problems}

The COVID-19 pandemic has led to huge challenges in the handling and controlling of hazardous medical waste (Tirkolaee et al. 2020a) and MSW. As mentioned, since the release of the coronavirus news in the world media, there was a rapid increase in essential commodities such as hand sanitizers, gloves, and face masks. According to the WHO modeling, 76 million gloves, 89 million masks, and 1.6 million goggles are needed per month, which is a growing demand that leads to huge waste generation (Kaufman and 
Chasan 2020). According to medical waste rules, medical wastes should be collected separately and should not be mixed with other wastes at any stage. However, during the pandemic and due to its quick spread nature, contaminated waste is not limited to healthcare centers or hospitals alone, and coronavirus has turned safe household waste into toxic waste, which should be treated as medical waste (Al Huraimel et al. 2020; Tabish et al. 2020). In the European Union (EU), infected wastes are required to be collected with a double bag. In Germany, normally, food containers would be categorized as recyclable waste; however, if the danger of contamination with coronavirus is available, they must be considered hazardous waste (Chakraborty et al. 2020). Households with suspected or positive COVID-19 cases are recommended to limit their separate waste collection system. This situation requires a fundamental structural change in all waste management sections, from the safety protocol for collection workers to pre-sorting/sorting rules, waste collection, and waste treatment (Chakraborty et al. 2020; Somani et al. 2020).

\section{Circular Economy during COVID-19 Pandemic}

This unexpected situation has forced countries to take a linear economy approach toward their waste management which includes extracting resources in order to produce new products and in the end, most of these products enter in landfill or even in the natural environment (Hahladakis et al. 2020; Payne et al. 2019). Approximately before the COVID-19 period, two billion people around the world did not possess waste collection facilities, and three billion did not have proper waste disposal systems (Wilson et al. 2015). Therefore, it is definitely not surprising that the linear economy has played a significant role in an increase in the aforementioned plastic waste crisis. To address the mentioned environmental problems regarding plastic and medical wastes, it is essential to move and take action toward more possible sustainable models, which is a circular economy. A circular economy is considered an alternative approach toward a traditional linear economy, including make, use, and disposal. This method tries to limit the usage of resources (reduce) and uses already existed materials again and again (reuse) as long as possible or consider waste as new sources (recycle and recover) by taking advantage of recycling or recovery facilities. Three main purposes of this method are shown in Fig. 3 (Hahladakis et al. 2020; Payne et al. 2019).

However, during the lockdown, a majority of the material recovery facilities were stopped because informal, formal, and local authorities have been worried about the risk of coronavirus spread among the waste handlers. Therefore, having proper waste facilities (including collection, transportation, and disposal) with considering minimal risks for health has led to a problem and challenge all around the world. All aforementioned challenges and the huge size of COVID-19 waste

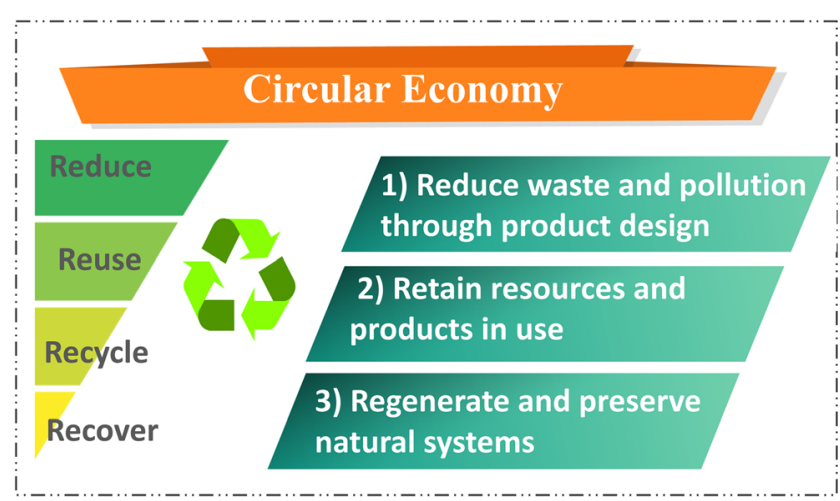

Fig. 3 Three main purposes of circular economy

generation amplify the need for specific consideration to new policies and techniques for contaminated waste during a global pandemic. In spite of the fact that COVID-waste management definitely is in its primary step, experiences from past diseases such as HIV-AIDS, MERS-CoV, and SARS-CoV-1 are considered to the early level along with the finding of new and proper ways to cope with coronavirus. Therefore, it is important to gather scatter information about coronavirus waste management by considering a circular economy with minimum risk of spreading the virus.

\section{Recommendation from Different International Organizations}

Recently, countries and agencies have updated their guidelines and added new policies that are related to COVID-19 waste management by considering no more health risks would be added during the pandemic. These different guidelines can be updated in the near future because they relied on recent knowledge of coronavirus and should be followed along with other existing rules which are related to plastic and medical waste management. New updates and recommendations related to COVID-19 waste management are presented by different guidelines in Table 1. Most of them emphasized the separation of wastes, which are created by the positive COVID-19 patient with other household waste. Moreover, infection waste should be separated and collected with a double-layer bag and definitely be marked as COVID waste. In addition, waste workers should have access to ample personal protective equipment, and social distancing should be observed in all places.

\section{Disinfection Technologies for COVID-19 Waste}

This section presents the most important technologies of disinfection and treatment of contamination wastes during the pandemic. 
Table. 1 Recommendations related to COVID waste management by countries or agencies

\begin{tabular}{|c|c|c|}
\hline Country/agency & Recommendations & Reference \\
\hline ISWA & $\begin{array}{l}\text { - In order to avoid cross-contamination, recycling activities should be re-adjusted. } \\
\text { - The increased values of medical and healthcare waste should be treated and disposed } \\
\text { of safely without risk of further pollution and infections. } \\
\text { - Social distancing should be observed. } \\
\text { - Use of adequate personal protective equipment. }\end{array}$ & ISWA 2020 \\
\hline WHO & $\begin{array}{l}\text { - Health care waste, where a suspected or infected patient by coronavirus is isolated, } \\
\text { collected in designated containers or bags, then safely treated or disposed of, preferably on-site. } \\
\text { - Use of adequate personal protective equipment. } \\
\text { - Only if suitable treatment and safe disposal are on-site, COVID-waste could be } \\
\text { transferred off-site. } \\
\text { - Social distancing should be observed. }\end{array}$ & WHO 2020 \\
\hline OSHA (USA) & $\begin{array}{l}\text { - Special precautions do not need for waste that is contaminated with coronavirus } \\
\text { beyond those already used as hazards waste management. } \\
\text { - Avoid processes like shredding waste. } \\
\text { - Use of adequate personal protective equipment. } \\
\text { - Social distancing should be observed. }\end{array}$ & OSHA 2020 \\
\hline USEPA (USA) & $\begin{array}{l}\text { - Attention to waste prevention if it is possible. } \\
\text { - COVID-19 patients wastes should be separately collected and disposed of from household waste. } \\
\text { - Maintaining sufficient segregation of recyclable waste. } \\
\text { - Use of adequate personal protective equipment. } \\
\text { - Considering longer-term storage of recyclable waste. }\end{array}$ & USEPA 2020 \\
\hline Basel Convention & $\begin{array}{l}\text { - Medical waste like contaminated gloves, masks used, and other items should be considered } \\
\text { hazardous waste then disposed of separately. } \\
\text { - These should be stored separately from household waste streams. } \\
\text { - Collected by waste management operators or specialist municipality. } \\
\text { - Use of adequate personal protective equipment. } \\
\text { - Social distancing should be observed. }\end{array}$ & Convention 2020 \\
\hline European Commission & $\begin{array}{l}\text { - Gloves and face masks for health workers and COVID-19 patients should be separated } \\
\text { from other wastes. } \\
\text { - Waste material produced for the cleaning where a COVID-19 patient was isolated should } \\
\text { be placed in the unsorted garbage. } \\
\text { - Use of adequate personal protective equipment. } \\
\text { - Social distancing should be observed. }\end{array}$ & Commission 2020 \\
\hline WIEGO & $\begin{array}{l}\text { - Provide adequate information on COVID-19 risks. } \\
\text { - Use of adequate personal protective equipment. }\end{array}$ & WIEGO 2020 \\
\hline China & $\begin{array}{l}\text { - Waste generated through treatment or prevention should be packaged with special standards } \\
\text { by using packaging bags, containers, and separated with warning signs, and considered } \\
\text { as medical waste. } \\
\text { - Incineration facilities for hazardous waste should be conducted with the obligations of the } \\
\text { proper health authorities. }\end{array}$ & Environment 2020 \\
\hline Japan & $\begin{array}{l}\text { - Separate non-infectious, infectious, and general wastes. } \\
\text { - Separate sharp items from another infectious waste with a suitable container. } \\
\text { - Seal the container, which is simple to employ and hard to break. }\end{array}$ & UN 2020 \\
\hline Italy & $\begin{array}{l}\text { - Waste generated by suspected or infected patients by COVID-19 should be separated and } \\
\text { considered as medical waste, and such waste should be collected with a double-layer bag. }\end{array}$ & SNPA 2020 \\
\hline India & $\begin{array}{l}\text { - Collect the blood waste and body fluids of COVID-19 patients in the yellow bags for } \bullet \text { the } \\
\text { people who are quarantined home. } \\
\text { - Attach a label "COVID-19 Waste" on infectious items. } \\
\text { - Daily sterilized with } 1 \% \text { solution of the sodium hypochlorite on (inside and outside) surfaces } \\
\text { of trolleys and containers. }\end{array}$ & UN 2020 \\
\hline
\end{tabular}

\section{High Heat Technologies}

Incineration: One of the most efficient waste-to-energy treatment processes, especially for recycling the plastic-based and inorganic proportion of waste, is incineration (INC) (Cobo et al. 2018; $\mathrm{Li}$ et al. 2012). The combustion range of INC relies on approximately 800 to $1200{ }^{\circ} \mathrm{C}$ temperature, which can entirely kill all viruses and bacteria (Datta et al. 2018). It turns out that most portion of the COVID wastes is transported to incinerate at almost above $1100{ }^{\circ} \mathrm{C}$ temperature. By considering the declined volume of COVID waste, the residual mass can be incinerated again among fresh charges (Ilyas et al. 2020). In addition, INC can play the main role in air pollution due to producing toxic substances such as dibenzofurans, dibenzodioxins, and chlorines. Thus, the flue- 
gas treatment facility is needed in order to reduce negative effects on air pollution, which increases the costs of this facility for operating systems (Chen et al. 2019; Voudrias 2016).

Pyrolysis: Pyrolysis operates at approximately between 540 and $830{ }^{\circ} \mathrm{C}$ temperature, including laser-based pyrolysis, inductionbased pyrolysis, and pyrolysis oxidation. In pyrolysis oxidation, liquid waste and organic solid inside the pyrolysis chamber vaporize at a temperature of $\sim 594{ }^{\circ} \mathrm{C}$ leaving behind metal fragments, glass, and ash. In the second step, the vapors combustion takes place in the chamber at $982-1093{ }^{\circ} \mathrm{C}$ temperature; later, clean exit steam is released. Considering the quick spread of the coronavirus, for rapid decomposition of COVID waste, plasma energy can be recommended instead of gaseous/laser combustion (Datta et al. 2018; Ilyas et al. 2020; Sogancioglu et al. 2017; Wang et al. 2020a; Zhao et al. 2018).

\section{Low Heat Technologies}

Microwave Disinfection: Microwave disinfection (MCD) consists of electromagnetic waves that have wavelengths ranging from almost 1 to $1000 \mathrm{~mm}$ (or sometimes frequency among 1000 to $3000 \mathrm{MHz}$ ) (Wang et al. 2020a). MCD is characterized by fast action, low energy consumption, little negative effect on the environment, higher heat yield, and without toxic residues or wastes after disinfection (Veronesi et al. 2005). MCD is a proper supplementary treatment instead of incineration, which can be designed under a specially controlled process that can help inactive SARS-CoV-2. This disinfection technique is so useful for on-site COVID waste. The benefit of on-site disinfection is that avoiding the dangers pose by the transportation of COVID waste as well as saving time is possible (Wang et al. 2020a). Although the heat resistance of the plastic compounds should be considered.

Autoclaves: The autoclave is considered a heat-based method in which water steam (temperature exceeding $100{ }^{\circ} \mathrm{C}$ ) is applied for sterilization. The steam can release latent heat that could destroy the microorganisms because of protein denaturation and coagulation on sanitary landfills, which are used for disposing of the treated waste (Emmanuel et al. 2001; Mir and Pandey 2019; Veronesi et al. 2005). However, it should be noted that this method is not suitable for all plastic types such as LDPE, HDPE, and PVC (Jonathan 2013).

\section{Chemical Disinfection}

Chemical disinfection can be used only when the size volume of contaminated wastes is small. Chemical disinfection is often utilized to pre-treat waste of COVID-19 and combined with earlier mechanical crushing (Hong et al. 2018). The crushed wastes are mixed with chemical disinfectants (calcium hypochlorite, chlorine dioxide, sodium hypochlorite, etc.) on sufficient time (under negative pressure) in order to deactivate infectious microorganisms. Chemical disinfectants are defined by stable performance, immediate effect, and broad sterilization spectrum for such as viruses, bacteria, and spores (Voudrias 2016). Chemical disinfection can be applied for COVID waste and can be divided into two main sub-groups, namely chlorine- and nonchlorine-based systems. Chlorinebased disinfection systems commonly consist of $\mathrm{ClO}_{2}$ or $\mathrm{NaOCl}$, where the chlorine electronegativity assists in peptide link oxidation and denaturing proteins that follow cell layers penetration even at neutral $\mathrm{pH}$. Sodium hypochlorite is one of the primary antiseptics releasing dioxins, chlorinated aromatic compounds, and halo acetic acid. The amount of available chlorine in $\mathrm{NaClO}$ is around 5-20\%. The mechanism of $\mathrm{NaClO}$ decontamination is (Eq. 1):

$\mathrm{NaClO}+\mathrm{H}_{2} \mathrm{O}=\mathrm{HOCl}+\mathrm{NaOH}$

After that, $\mathrm{ClO}_{2}$ extended, which is a potent biocide, is used on-site due to its unstable nature. Besides, it decomposes to the formation of salt and less-toxic compounds, which are nonreactive to ammonia/alcohol. $\mathrm{H}_{2} \mathrm{O}_{2}$ is used as a nonchlorine-based disinfection system as the disinfectant substance. It can denature and oxidize lipids and proteins, and it also can disorganize the membrane by swelling the $\mathrm{H}^{+}$-ions. A chlorinated system is more convenient to use due to its non-toxicity and high reactivity. Moreover, some chemical solutions such as ethyl alcohol ( $>75 \%)$, isopropanol $(>70 \%)$, povidone-iodine $(>0.23 \%)$, and formaldehyde $(>0.7 \%)$ can effectively inactivate coronavirus (Duarte and Santana 2020).

\section{Disinfection Methods for Reprocessing of Personal Protective Equipment}

Reusing of the PPE is a promising temporary solution during the coronavirus outbreak where there is definitely growing proof for the efficient extension of reprocessing ways, including dry heat, hydrogen peroxide vapor, ozone, and UV light at $2000 \mathrm{~mJ} / \mathrm{cm}^{2}$ $(254 \mathrm{~nm})$, in which most of the reported methods are the use of hydrogen peroxide vapor $\left(\mathrm{VH}_{2} \mathrm{O}_{2}\right)$ (Rowan and Laffey 2020b). These mentioned disinfection methods and viral inactivation are related to the transformation of structural factors, which include an outer envelope, RNA genome, and a protein capsid (Pinon and Vialette 2018). The other important points for effective PPE disinfection are conserving PPE integrity, especially fit and filtering ability, being non-toxicity, and safety.

Using Hydrogen Peroxide Vapor: The Food and Dry Administration (FDA) had permitted the $\mathrm{VH}_{2} \mathrm{O}_{2}$ method, under Emergency Use Authorization (EUA), to reprocess N95 face masks in the USA during the COVID-19 pandemic, which was based on the studies of the Columbus-based Battelle (Battelle 2016). The background of applying 
$\mathrm{VH}_{2} \mathrm{O}_{2}$ and its advantages, which is considered a reprocessing operator and sterilizing manner for medical device usages, have been precisely studied by Rowan and Mcevoy in 2019 (McEvoy and Rowan 2019). The Centers for Disease Control and Prevention (CDC) investigated all related publications on $\mathrm{VH}_{2} \mathrm{O}_{2}$ decontamination of filtering facepiece respirators (FFRs) to prepare the proof of minimum filtration effects with high efficiency of $99.99 \%$ in destroying bacterial spores (CDC 2020; Rowan and Laffey 2020b).

Moreover, MaimunaJatta et al. illustrated the N95 respirator decontamination by $\mathrm{VH}_{2} \mathrm{O}_{2}(59 \%)$ could be safely applied to disinfect single-use N95 respirators without notable effects on quantitative fit testing or efficiency of the filtration (Jatta et al. 2020). However, Bergman et al. reported that filtration efficiency adversely had been affected by three periods of gas plasma treatment, mainly applying the STERRAD $100 \mathrm{~S}_{2} \mathrm{O}_{2}$ gas plasma decontaminant (Bergman et al. 2010; Rowan and Laffey 2020b).

Using Ozone for Reprocessing of PPE: Ozone can break up proteins and lipids in the virus envelope by exposing crucial genetic material; hence, it causes oxidative inactivation (Rowan 2019). Dennis et al. investigated the viricidal ozone potential by performing a simple system of the disinfection box for FFRs. They suggested concentrations of the ozone at 10 to $20 \mathrm{mg} / \mathrm{L}$ combined with at least 10-min exposure for effective viral inactivation. Moreover, they reported the merits of ozone, including fast viricidal action, which is practicable for fibrous stuff. However, Dennis et al. also informed us about the ozone demerits such as lung irritants, and it can be risky to humans and other creatures (Dennis et al. 2020). There is minimal reported data on ozone for medical devices and wider PPE treatment because of the potential risk connected with its lung health implications and volatility (Rowan and Laffey 2020b).

Using Ultraviolet Light for Reprocessing of PPE: Ultraviolet irradiation (UV) causes the inactivation of viruses by destroying their nucleic acids (RNA) with a photodimerization procedure (Darnell et al. 2004). Optimum irreversible damage of molecules happens around the 254-nm wavelength in the UVC area (200-280 nm) (Bergman et al. 2020; Rowan 2019). Moreover, the CDC (CDC 2020) indicated that UV germicidal irradiation (UVGI) is a proper way for PPE reusing. However, it noted that not all ultraviolet lamps could present equal intensity. Besides, UVGI is improbable to destroy all different kinds of bacteria and viruses in the FFR because of the effects of shadow created by the multifold-layer FFR fabrication. Lindsley et al. noted that the performance of the suitable filtration was studied for the eleven types of FFR, which were exposed to diverse ranging of the UV doses from $0.5-950 \mathrm{~J} / \mathrm{cm}^{2}$ (Lindsley et al. 2015). Heimbuch and Harnish examined fit and filtration of 15
FFRs and no unfavorable impacts on FFR action were found (Heimbuch and Harnish 2019). O'Hearn et al. systematically reviewed UV decontamination of $\mathrm{N} 95$ respirators, and a cumulative UV dose or fluence of $40,000 \mathrm{~J} / \mathrm{m}^{2}$ in the coming confirmation researches such as fit, filtration, and transformation testing is suggested (O'Hearn et al. 2020). Recently, Lowe et al. (2020) studied the effective inactivation use of UVGI for a range of problematic human pathogens, such as COVID-19, focusing on FFP respirator (N95) decontamination.

Using Dry Heat for Reprocessing of PPE: Several kinds of research have focused on the application of various heating regimes for PPE reprocessing, which is causing irreversible structural hurt in virus proteins that prevents binding from hosting cells (Derraik et al. 2020). Generally, heat procedure for $\geq 30 \mathrm{~min}$ at $60{ }^{\circ} \mathrm{C}$ leads to $\sim 4.6$ to $7 \log _{10}$ reduction in coronavirus. Duplicating the exposure period for $60 \mathrm{~min}$ at $60{ }^{\circ} \mathrm{C}$ could be wiser, due to the variability in heat inactivation reports for coronavirus (Derraik et al. 2020). Song et al. investigated the heating of the facemasks in the oven at $56{ }^{\circ} \mathrm{C}$ for about $30 \mathrm{~min}$ with hot air from a hairdryer without examining the efficacy in the capacity of filtering to inactive the influenza virus (Song et al. 2020). Jung et al. evaluated several decontamination methods for reusing respirators and compared their impact on the filtration capability and bacterial elimination. A short-term UV irradiation and oven-dry mainly conserved the filtration efficiency. However, the disadvantage of these methods is the incomplete sterilization efficiency in a severe microbial environment (Jung et al. 2021). All the mentioned methods are summarized in Table 2.

\section{Future Outlook and Recommendation}

Many international agreements and guidelines on plastics have been reported to reduce and address their impact on universal pollution; however, the COVID-19 pandemic has made the situation worse. Therefore, it is necessary to rethink the actions taken during the COVID-19 pandemic to minimize future negative consequences. Some recommendations for properly managing plastic and medical waste are included in three sections (Fig. 4).

\section{Increase Public Awareness}

It is necessary to revise our viewpoints on plastic consumption by elevating sustainable behaviors, abandoning old habits, and adjusting to novel ones. Also, it is vital to motivate scientific research to achieve this target for an impressive communicative method as well as decision-makers who are struggling to detect related communication channels in order to enhance the environmental knowledge and information of the society. Government 
Table. 2 The most important technologies of disinfection and treatment of contamination wastes

\begin{tabular}{|c|c|c|c|}
\hline Disinfection technology & Advantages & Disadvantages & References \\
\hline Incineration technique & $\begin{array}{l}\text { - Simple operation } \\
\text { - Reduce waste volume by up to } 90 \% \\
\text { - Complete destruction of COVID-waste }\end{array}$ & $\begin{array}{l}\text { - High investment costs } \\
\text { - Energy consumption } \\
\text { - Releasing secondary pollutants (dioxin } \\
\quad \text { and furans) }\end{array}$ & $\begin{array}{l}\text { Datta et al. 2018; Shah et al. 2020; } \\
\text { Wang et al. 2020a }\end{array}$ \\
\hline Pyrolysis technique & $\begin{array}{l}\text { - Energy-saving } \\
\text { - Decomposition of COVID-waste volume } \\
\text { - Destruction of toxins such as dioxins and furan }\end{array}$ & $\begin{array}{l}\text { - High investment costs } \\
\text { - Energy-intensive } \\
\text { - It could not be considered a safe technology }\end{array}$ & $\begin{array}{l}\text { Datta et al. 2018; Wang et al. } \\
\text { 2020a }\end{array}$ \\
\hline Microwave technique & $\begin{array}{l}\text { - Energy can be saved because of low action temperature } \\
\text { - It can be considered as a mobile facility in the treatment site }\end{array}$ & $\begin{array}{l}\text { - Narrow disinfection spectrum } \\
\text { - Complex impact factors }\end{array}$ & $\begin{array}{l}\text { Datta et al. 2018; Wang et al. } \\
\text { 2020a }\end{array}$ \\
\hline Autoclave & - It does not release toxic gases & - It is not suitable for all plastic types & Jonathan 2013 \\
\hline Chemical technique & $\begin{array}{l}\text { - Stable performance } \\
\text { - Rapid action } \\
\text { - Broad sterilization spectrum } \\
\text { - Controlling virus spread }\end{array}$ & $\begin{array}{l}\text { - Could not reduce the mass and volume of waste } \\
\text { - Residual disinfectants }\end{array}$ & $\begin{array}{l}\text { Ilyas et al. 2020; Mallapur 2020; } \\
\text { Rowan and Laffey 2020a; } \\
\text { Singh et al. 2020a }\end{array}$ \\
\hline Vaporized hydrogen peroxide & $\begin{array}{l}\text { - After complete disinfection, reuse or reprocessing } \\
\text { of protective items is possible }\end{array}$ & $\begin{array}{l}\text { - Causing skin, alveoli, and mucosa } \\
\text { health problems }\end{array}$ & $\begin{array}{l}\text { Barcelo 2020; Ilyas et al. 2020; } \\
\text { McEvoy and Rowan } 2019\end{array}$ \\
\hline Dry heat technique & $\begin{array}{l}\text { - Suitable for polymeric material in order to reprocess } \\
\text { - Mitigating the threat of supply chain by reusing, } \\
\text { for example, N95 masks or PPE }\end{array}$ & $\begin{array}{l}\text { - Decontamination of the trapped virus } \\
\text { is unanswered }\end{array}$ & Ilyas et al. 2020; Price et al. 2020 \\
\hline Ozone & - Oxidative inactivation of the virus & - Lung irritants & $\begin{array}{l}\text { Rowan and Laffey } 2020 \mathrm{~b} ; \\
\text { Silva et al. } 2020\end{array}$ \\
\hline ultraviolet light (UV) & $\begin{array}{l}\text { - Inactivation of viruses by destroying } \\
\text { their nucleic acids }\end{array}$ & $\begin{array}{l}\text { - Low performance because of shadow created by } \\
\text { the multifold layers of the FFR's construction }\end{array}$ & Darnell et al. 2004 \\
\hline
\end{tabular}

policy, personal responsibility, and their corporations are all pivotal to conserve us from one disaster to a new one.

People can decrease the recycling workload by doing home separation, and authorities should try to increase awareness of individuals about challenges that the waste management sector is struggling with during the COVID-19 crisis, and this could be done by utilizing campaigns, advertisements, social media, etc. Moreover, it needs to ensure that people involved are properly trained to deal with hazardous biomedical waste, which can be happened by creating a platform for universal common knowledge-sharing.

\section{Improvement in Waste Management}

During the coronavirus epidemic, it is important to gather valid data about the type and quantity of waste and which type of material can be reused, recycled, or transferred to incineration or landfill. However, most guideline updates or available technologies are not completely fit with the current situation. Therefore, strong policies, regulations, and safe techniques related to different parts of waste management, such as separation, collecting, transporting, treatment, and disposal, are needed. During the pandemic, waste management is significant because of the potential of pathogen transmission or increased plastic and medical waste generation. Governments should improve their waste management, aiming at reaching maximum collection, reusing, and recycling facilities. In order to improve the recyclability potential of medical waste, pre-sorting and disinfection are mandatory factors (Prata et al. 2019; Silva et al. 2020).

Moreover, decontamination technology, such as $\mathrm{VH}_{2} \mathrm{O}_{2}$, ozone, and UV, can suggest a sustainable strategy for waste and wastewater treatment. The choice of a proper decontamination technology must rely on the quantity of waste, costs, waste type, and maintenance. Incineration can be the best option for infectious medical waste in heavy volumes of $(>10 \mathrm{t} /$ day), and it totally kills pathogens because of the hightemperature utilized (above $800{ }^{\circ} \mathrm{C}$ temperature). In addition, if the medical waste quantity is not considered too high ( $<10 \mathrm{t} /$ day $)$, physical disinfection (high-temperature steam or microwave) or chemical decontamination (i.e., applying chemical disinfectants) might be an option (Gertsman et al. 2020). Ultimately, medical waste treatment facilities must be more automatic, with a minimum of personnel involved.

\section{Improvement in Modern Sustainable Technology}

Even though the consumption of plastics remarkably improved our life quality, it is pivotal to transfer to sustainable alternatives, like bio-based plastics. Bio-based plastics can enhance recycling aims and waste management efficiency and reduce carbon footprint. Thus, economic and environmental pressure caused by conventional and fuel-based plastic substrates reduces (Napper and Thompson 2019). Moreover, bio-based biodegradable plastics have extra benefits because they decompose due to biological or enzymatic activities through open air. Bioplastics are made partly or entirely from biological polymers such as cane, potato, starch, cellulose, sugar, cotton, and straw. Aliphatic and furanicaliphatic polyesters are also given special attention as PPE building blocks and other disposable plastics because of their adjustable degradation levels and sustainable thermophysical characteristics (Shen et al. 2020; Sousa et al. 2015; Zhang et al. 2018).

The development of eco-friendly materials such as bioplastics and the use of modern sustainable technologies play a key role in combating future pandemics. However, the latest study 
Fig. 4 Recommendations for the future by considering three significant parts

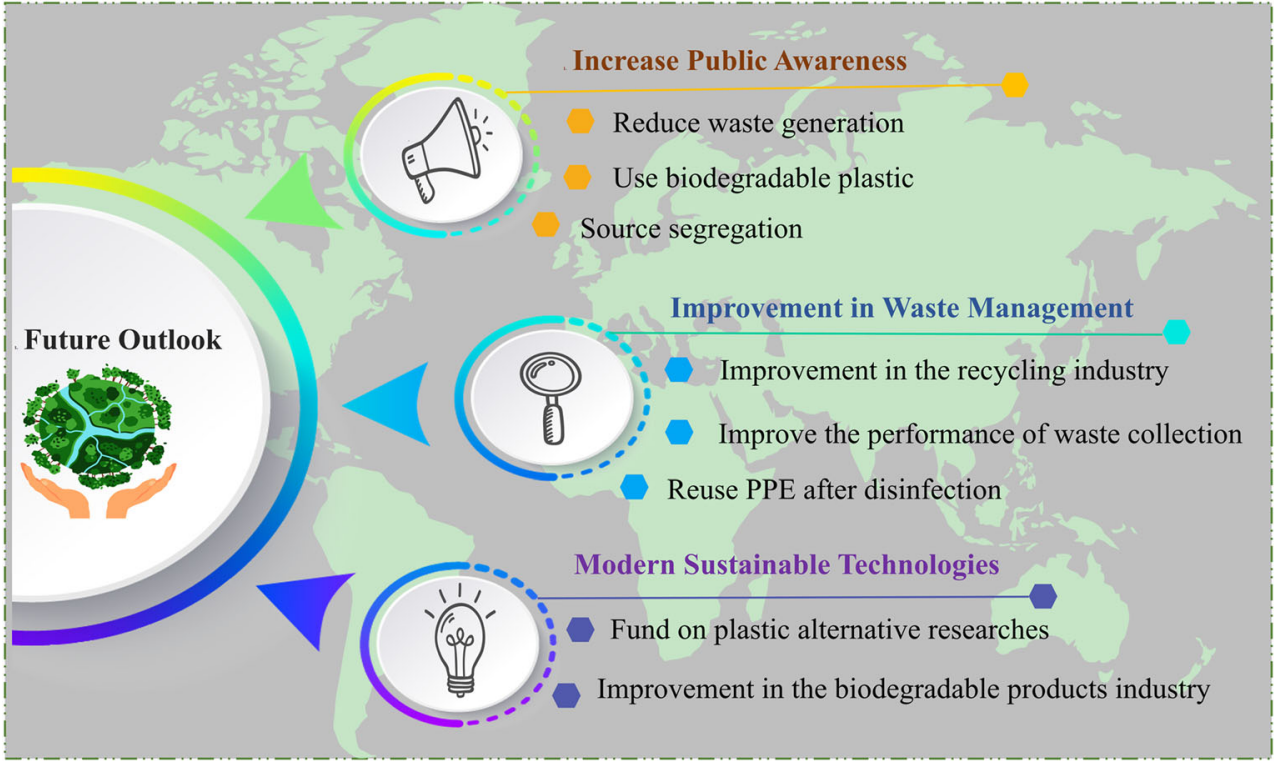

demonstrated that oxo-biodegradable and biodegradable plastic formulations' functional preserved after 3 years in the marine and soil environments (Napper and Thompson 2019). For example, polysaccharide-based material-filled natural rubber latex (PFNRL) gloves are in the category of biodegradable gloves. The shelf life of the PFNRL glove was evaluated at almost 3 years, while its tensile strength decreased at $30{ }^{\circ} \mathrm{C}$ to $75 \%$ retention in shift factor and Arrhenius models (Ab Rahman et al. 2020). Investing in research on alternatives to plastic can lead to the improvement in sustainable and novel methods and technologies to reuse mixed and complex plastic packaging. For example, investing in emerging applied sciences, namely chemical reprocessing, leads to well quality chemicals and resins even after mixing plastic waste (Vollmer et al. 2020). As mentioned before, bioplastic is not the final and proper solution. Thus, intense testing for degradability or recyclability of bioplastic quality before entering the market and simplifying infrastructure for practicable bioplastic waste management must be ensured as well. CDC also has recommended home-made cloth face masks for employ in the general public. Home-made face masks with manifold layers can be efficient against the transmission of COVID-19 through respiratory droplets during pandemics and mask deficiencies. Face masks made from materials like cotton fabrics allow washing and reusing; so, they can help to reduce the unfavorable environmental effects of extensive usage of nonbiodegradable and commercial disposable face masks (Aydin et al. 2020).

\section{Conclusion}

The COVID-19 pandemic is the abrupt surge in the plastic and medical waste volume, especially for personal protection products and healthcare purposes. In this paper, the effects of the COVID-19 pandemic on plastic and medical wastes are comprehensively reviewed. Moreover, the potential of reusing processes and treatments of contamination on plastic wastes were also discussed with a circular economy perspective. A future in which all different kinds of plastics are reused and recycled can be envisioned by novel sustainable technologies in the present waste management system. Ultimately, government policy, personal responsibility, and their corporations are all pivotal to conserve us from one disaster to a new one.

Funding The authors would like to gratefully thank the Amir Kabir University of Technology (AUT), Tehran, Iran, for their financial support.

\section{Declarations}

Disclaimer The authors whose names are listed in this paper certify that they have NO affiliations with or involvement in any organization or entity with any financial interest (such as honoraria; educational grants; participation in speakers' bureaus; membership, employment, consultancies, stock ownership, or other equity interest; and expert testimony or patent-licensing arrangements), or non-financial interest (such as personal or professional relationships, affiliations, knowledge or beliefs) in the subject matter or materials discussed in this manuscript.

\section{References}

Ab Rahman MF, Rusli A, Misman MA, Rashid AA (2020) Biodegradable gloves for waste management post-COVID-19 outbreak: a shelf-life prediction. ACS Omega 5:30329-30335

Abu-Qdais H, Al-Ghazo M, Al-Ghazo E (2020) Statistical analysis and characteristics of hospital medical waste under novel Coronavirus 
outbreak. Global Journal of Environmental Science and Management 6:21-30

Al Huraimel K, Alhosani M, Kunhabdulla S, Stietiya MH (2020) SARSCoV-2 in the environment: modes of transmission, early detection and potential role of pollutions. Sci Total Environ: 140946

Anderson EL, Turnham P, Griffin JR, Clarke CC (2020) Consideration of the aerosol transmission for COVID-19 and public health risk analysis

Aydin O, Emon B, Cheng S, Hong L, Chamorro LP, Saif MTA (2020) Performance of fabrics for home-made masks against the spread of COVID-19 through droplets: a quantitative mechanistic study. Extreme Mechanics Letters 40:100924

Barcelo D (2020) An environmental and health perspective for COVID19 outbreak: meteorology and air quality influence, sewage epidemiology indicator, hospitals disinfection, drug therapies and recommendations. J Environ Chem Eng:104006

Battelle (2016) Final report for the bioquell hydrogen peroxide vapor (HPV) decontamination for re-use of N95 respirators. https://www. fda.gov/emergency-preparedness-and-response/mcm-regulatoryscience/investigating-decontamination-and-reuse-respiratorspublic-health-emergencies

Behera PR, Farzana R, Sahajwalla V (2020) Reduction of oxides obtained from waste Ni-MH battery's positive electrode using waste plastics to produce nickel based alloy. J Clean Prod 249:119407

Bengali S (2020) The COVID-19 pandemic is unleashing a tidal wave of plastic waste The Los Angeles Times

Bergman MS, Viscusi DJ, Heimbuch BK, Wander JD, Sambol AR, Shaffer RE (2010) Evaluation of multiple (3-cycle) decontamination processing for filtering facepiece respirators. Journal of Engineered Fibers and Fabrics 5:155892501000500405

Bergman M, Fisher EM, Heimbuch BK (2020) A review of decontamination methods for filtering facepiece respirators. Journal of the International Society for Respiratory Protection 37:71

Bigdeloo M, Teymourian T, Kowsari E, Ramakrishna S, Ehsani A (2021) Sustainability and circular economy of food wastes: waste reduction strategies, higher recycling methods, and improved valorization. Materials Circular Economy 3:3. https://doi.org/10.1007/s42824021-00017-3

Braga F, Scarpa GM, Brando VE, Manfè G, Zaggia L (2020) COVID-19 lockdown measures reveal human impact on water transparency in the Venice Lagoon. Sci Total Environ:139612

CDC (2020) Centers for Disease Control and Prevention. Coronavirus disease - decontamination and re-use. https://www.cdc.gov/ coronavirus/2019-ncov/hcp/ppe-strategy/decontamination-reuserespirators.html Accessed 10th July, 2020

Chakraborty I, Maity P (2020) COVID-19 outbreak: migration, effects on society, global environment and prevention. Sci Total Environ: 138882

Chakraborty T, Islam M, Zaman S, Kabir A, Ghosh G (2020) Jute (Corchorus olitorius) stick charcoal as a low-cost adsorbent for the removal of methylene blue dye from aqueous solution SN. Appl Sci 2:1-10

Chan JF-W et al (2020) A familial cluster of pneumonia associated with the 2019 novel coronavirus indicating person-to-person transmission: a study of a family cluster. Lancet 395:514-523

Chang A et al (2020) Cleaning and disinfectant chemical exposures and temporal associations with COVID-19-National Poison Data System, United States, January 1, 2020-March 31, 2020. Morb Mortal Wkly Rep 69:496

Chauhan A, Jakhar SK, Chauhan C (2020) The interplay of circular economy with industry 4.0 enabled smart city drivers of healthcare waste disposal. J Clean Prod 279:123854

Chen L, Wang L, Cho DW, Tsang DCW, Tong L, Zhou Y, Yang J, Hu Q, Poon CS (2019) Sustainable stabilization/solidification of municipal solid waste incinerator fly ash by incorporation of green materials. J Clean Prod 222:335-343
Chin A et al. (2020) Stability of SARS-CoV-2 in different environmental conditions MedRxiv

Cobo S, Dominguez-Ramos A, Irabien A (2018) From linear to circular integrated waste management systems: a review of methodological approaches. Resour Conserv Recycl 135:279-295

Commission E (2020) Waste management in the context of coronavirus crisis. https://ec.europa.eu/info/sites/info/files/waste_management guidance_dg-env.pdf. Accessed 25 May 2020

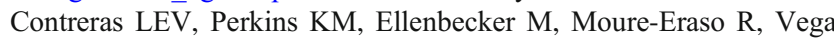
NEM (2020) COVID-19 pandemic lessons to facilitate future engagement in the global climate crisis. J Clean Prod:125178

Convention B (2020) Waste management an essential public service in the fight to beat COVID-19. http://www.basel.int/Implementation/ PublicAwareness/PressReleases/-WastemanagementandCOVID19/ tabid/8376/Default.aspx. Accessed 20 May 2020

Darnell ME, Subbarao K, Feinstone SM, Taylor DR (2004) Inactivation of the coronavirus that induces severe acute respiratory syndrome, SARS-CoV. J Virol Methods 121:85-91

Das O et al (2020) The need for fully bio-based facemasks to counter coronavirus outbreaks: a perspective. Sci Total Environ:139611

Datta P, Mohi GK, Chander J (2018) Biomedical waste management in India: critical appraisal Journal of laboratory physicians 10:6

Dennis R, Cashion A, Emanuel S, Hubbard D (2020) Ozone gas: scientific justification and practical guidelines for improvised disinfection using consumer-grade ozone generators and plastic storage boxes. J Sci Med:2

Derraik JG, Anderson WA, Connelly EA, Anderson YC (2020) Rapid review of SARS-CoV-1 and SARS-CoV-2 viability, susceptibility to treatment, and the disinfection and reuse of PPE, particularly filtering facepiece respirators. Int J Environ Res Public Health 17: 6117

Di Maria F et al (2020a) Minimization of spreading of SARS-CoV-2 via household waste produced by subjects affected by COVID-19 or in quarantine. Sci Total Environ 743:140803

Di Maria F, Sisani F, Contini S, Ghosh SK, Mersky RL (2020b) Is the policy of the European Union in waste management sustainable? An assessment of the Italian context. Waste Management 103:437-448

Dietz L, Horve PF, Coil DA, Fretz M, Eisen JA, Van Den Wymelenberg K (2020) 2019 novel coronavirus (COVID-19) pandemic: built environment considerations to reduce transmission. Msystems 5

Ding Z, Chen H, Liu J, Cai H, Evrendilek F, Buyukada M (2020) Pyrolysis dynamics of two medical plastic wastes: drivers, behaviors, evolved gases, reaction mechanisms, and pathways. J Hazard Mater 402:123472

Duarte P, Santana VT (2020) Disinfection measures and control of SARS-COV-2 transmission global biosecurity 1

Dutheil F, Baker JS, Navel V (2020) COVID-19 as a factor influencing air pollution? Environmental Pollution (Barking, Essex: 1987) 263: 114466

Emmanuel J, Puccia C, Spurgin R (2001) Non-incineration medical waste treatment technologies Washington (DC): health care without harm

Environment MoEa (2020) Guidelines for the Management and Technology of Emergency Disposal of Medical Wastes of Pneumonia with New Coronavirus Infection (Trial). http://www. gov.cn/xinwen/2020-01/29/content 5472997.htm. Accessed 1.13. 2021

Fadare OO, Okoffo ED (2020) Covid-19 face masks: a potential source of microplastic fibers in the environment. Sci Total Environ 737 : 140279

Faridi S, Niazi S, Sadeghi K, Naddafi K, Jila Y, Mansour S, Shafiei JNZ, Khosro S, Ramin N, Masud Y, Fatemeh M, Adel M, Sadegh HM, Talat MA (2020) A field indoor air measurement of SARS-CoV-2 in the patient rooms of the largest hospital in Iran. Sci Total Environ 725:1-5

Gertsman S et al. (2020) Microwave-and heat-based decontamination of N95 filtering facepiece respirators (FFR): a systematic review 
Hahladakis JN, Iacovidou E, Gerassimidou S (2020) Plastic waste in a circular economy. In: Plastic Waste and Recycling. Elsevier, pp. 481-512

Heimbuch B, Harnish D (2019) Research to mitigate a shortage of respiratory protection devices during public health emergencies applied research associates: 275

Heller L, Mota CR, Greco DB (2020) COVID-19 faecal-oral transmission: are we asking the right questions? Sci Total Environ:138919

Hong J, Zhan S, Yu Z, Hong J, Qi C (2018) Life-cycle environmental and economic assessment of medical waste treatment. J Clean Prod 174: $65-73$

Ilyas S, Srivastava RR, Kim H (2020) Disinfection technology and strategies for COVID-19 hospital and bio-medical waste management. Sci Total Environ 749:141652

ISWA (2020) Waste Management during the Covid-19 pandemic ISWA's recommendations. https://www.iswa.org/fileadmin/galleries/0001 COVID/ISWA Waste Management During COVID19.pdf. Accessed 20 May 2020

ItalyWWF (2020) In the disposal ofmasks and gloves, responsibility is required.WWF International. https://www.wwf.it/chi siamo/ organizzazione. Accessed 8 June 2020

Jatta M, Kiefer C, Patolia H, Pan J, Harb C, Marr LC, Baffoe-Bonnie A (2020) N95 reprocessing by low temperature sterilization with $59 \%$ vaporized hydrogen peroxide during the 2020 COVID-19 pandemic. Am J Infect Control

Jiang P, Fu X, Van Fan Y, Klemeš JJ, Chen P, Ma S, Zhang W (2021) Spatial-temporal potential exposure risk analytics and urban sustainability impacts related to COVID-19 mitigation: a perspective from car mobility behaviour. J Clean Prod 279:123673

Jonathan (2013) What plastic materials are safe for autoclaving? https:// www.oberk.com/packaging-crash-course/5-questions-aboutautoclaving-plastic-bottles-and-glass-bottles

Jung S, Hemmatian T, Song E, Lee K, Seo D, Yi J, Kim J (2021) Disinfection treatments of disposable respirators influencing the bactericidal/bacteria removal efficiency, filtration performance, and structural integrity. Polymers 13:45

Kampf G, Todt D, Pfaender S, Steinmann E (2020) Persistence of coronaviruses on inanimate surfaces and their inactivation with biocidal agents. J Hosp Infect 104:246-251

Kaufman L, Chasan E (2020) Cities wonder whether recycling counts as essential during the virus. Bloomberg Green

Kitajima M et al (2020) SARS-CoV-2 in wastewater: state of the knowledge and research needs. Sci Total Environ:139076

Klemeš JJ, Van Fan Y, Tan RR, Jiang P (2020) Minimising the present and future plastic waste, energy and environmental footprints related to COVID-19. Renew Sust Energ Rev 127:109883

Kulkarni BN, Anantharama V (2020) Repercussions of COVID-19 pandemic on municipal solid waste management: challenges and opportunities. Sci Total Environ 743:140693

Kumar H, Azad A, Gupta A, Sharma J, Bherwani H, Labhsetwar NK, Kumar R (2020) COVID-19 creating another problem? Sustainable solution for PPE disposal through LCA approach. Environ Dev Sustain:1-15

Lewis D (2020) Is the coronavirus airborne? Experts can't agree. Nature $580: 175$

Li X-G, Lv Y, Ma B-G, Chen Q-B, Yin X-B, Jian S-W (2012) Utilization of municipal solid waste incineration bottom ash in blended cement. J Clean Prod 32:96-100

Lindsey P et al (2020) Conserving Africa's wildlife and wildlands through the COVID-19 crisis and beyond. Nat Ecol Evol 4:13001310

Lindsley WG, Martin SB, Thewlis RE, Sarkisian K, Nwoko JO, Mead KR, Noti JD (2015) Effects of Ultraviolet Germicidal Irradiation (UVGI) on N95 Respirator Filtration Performance and Structural Integrity. J Occup Environ Hyg 12(8):509-517
Lowe JJ, Paladino, K.D., Farke, J.D., Boulter, K., Cawcutt, K., Emodi, M., Gibbs, S., Hankins, R., Hinkle, L., Micheels, T., Schwedhelm, S., Vasa, A., Wadman, M., Watson, S., Rupp, M.E (2020) N95 filtering facemask respirator ultraviolet germicidal irradiation (UVGI) process for decontamination and reuse. Nebrasca Medicine

Malgorzata G-J, Krawczyk A, Jurczak A, Strzelecka M, Rechciński M, Boćkowski M (2020) Environmental: choices vs. COVID-19 pandemic fear-plastic governance re-assesment. Society Register 4:49-66

Mallapur C (2020) Sanitation workers at risk from discarded medical waste related to COVID-19 IndiaSpend URL: https://www. indiaspend com/sanitation-workersat-risk-from-discarded-medicalwaste-related-tocovid-19

Manenti R et al (2020) The good, the bad and the ugly of COVID-19 lockdown effects on wildlife conservation: insights from the first European locked down country. Biol Conserv 249:108728

Manupati VK, Ramkumar M, Baba V, Agarwal A (2020) Selection of the best healthcare waste disposal techniques during and post COVID19 pandemic era. J Clean Prod 281:125175

McEvoy B, Rowan NJ (2019) Terminal sterilization of medical devices using vaporized hydrogen peroxide: a review of current methods and emerging opportunities. J Appl Microbiol 127:1403-1420

Mir RA, Pandey O (2019) Waste plastic derived carbon supported Mo2C composite catalysts for hydrogen production and energy storage applications. J Clean Prod 218:644-655

Monella LM (2020) Will plastic pollution get worse after the COVID-19 pandemic? https://www.euronews.com/2020/05/12/will-plasticpollution-get-worseafter-the-covid-19-pandemic. Accessed 8 June 2020

Morawska L, Cao J (2020) Airborne transmission of SARS-CoV-2: the world should face the reality. Environ Int:105730

Muhammad S, Long X, Salman M (2020) COVID-19 pandemic and environmental pollution: a blessing in disguise? Sci Total Environ: 138820

Napper IE, Thompson RC (2019) Environmental deterioration of biodegradable, oxo-biodegradable, compostable, and conventional plastic carrier bags in the sea, soil, and open-air over a 3-year period. Environ Sci Technol 53:4775-4783

Nghiem LD, Morgan B, Donner E, Short MD (2020) The COVID-19 pandemic: considerations for the waste and wastewater services sector. Case studies in chemical and environmental engineering:100006

Nowakowski P, Kuśnierz S, Sosna P, Mauer J, Maj D (2020) Disposal of personal protective equipment during the COVID-19 pandemic is a challenge for waste collection companies and society: a case study in Poland. Resources 9:116

Nzediegwu C, Chang SX (2020) Improper solid waste management increases potential for COVID-19 spread in developing countries resources. Conservation, and Recycling 161:104947

O'Hearn K et al. (2020) Decontaminating N95 masks with ultraviolet germicidal irradiation (UVGI) does not impair mask efficacy and safety: a systematic review

OSHA U (2020) COVID-19. https://www.osha.gov/SLTC/covid-19/ controlprevention.html\#solidwaste. Accessed 5.17.20

Pakravan-Charvadeh MR, Mohammadi-Nasrabadi F, Gholamrezai S, Vatanparast H, Flora C, Nabavi-Pelesaraei A (2020) The shortterm effects of COVID-19 outbreak on dietary diversity and food security status of Iranian households (a case study in Tehran province). J Clean Prod: 124537

Payne J, McKeown P, Jones MD (2019) A circular economy approach to plastic waste. Polym Degrad Stab 165:170-181

Phan LT, Nguyen TV, Luong QC, Nguyen TV, Nguyen HT, le HQ, Nguyen TT, Cao TM, Pham QD (2020) Importation and humanto-human transmission of a novel coronavirus in Vietnam. N Engl J Med 382:872-874

Pinon A, Vialette M (2018) Survival of viruses in water. Intervirology 61: 214-222 
Prata JC, Silva ALP, Da Costa JP, Mouneyrac C, Walker TR, Duarte AC, Rocha-Santos T (2019) Solutions and integrated strategies for the control and mitigation of plastic and microplastic pollution. Int $\mathrm{J}$ Environ Res Public Health 16:2411

Prata JC, Silva AL, Walker TR, Duarte AC, Rocha-Santos T (2020) COVID-19 pandemic repercussions on the use and management of plastics. Environ Sci Technol 54:7760-7765

Price AD et al. (2020) Is the fit of N95 facial masks effected by disinfection? A study of heat and UV disinfection methods using the OSHA protocol fit test medRxiv

Rowan NJ (2019) Pulsed light as an emerging technology to cause disruption for food and adjacent industries-quo vadis? Trends Food Sci Technol 88:316-332

Rowan NJ, Laffey JG (2020a) Challenges and solutions for addressing critical shortage of supply chain for personal and protective equipment (PPE) arising from coronavirus disease (COVID19) pandemic-case study from the Republic of Ireland. Sci Total Environ: 138532

Rowan NJ, Laffey JG (2020b) Unlocking the surge in demand for personal and protective equipment (PPE) and improvised face coverings arising from coronavirus disease (COVID-19) pandemicimplications for efficacy, re-use and sustainable waste management. Sci Total Environ: 142259

Rutz C et al (2020) COVID-19 lockdown allows researchers to quantify the effects of human activity on wildlife. Nat Ecol Evol 4:11561159

Ryan PG, Maclean K, Weideman EA (2020) The impact of the COVID19 lockdown on urban street litter in South Africa. Environmental Processes 7:1303-1312

Saadat S, Rawtani D, Hussain CM (2020) Environmental perspective of COVID-19. Sci Total Environ:138870

Scaraboto D, Joubert A, Gonzalez-Arcos C (2020) Using lots of plastic packaging during the coronavirus crisis? You're not alone. Conversation 668:1077-1093

Severo EA, De Guimarães JCF, Dellarmelin ML (2020) Impact of the COVID-19 pandemic on environmental awareness, sustainable consumption and social responsibility: evidence from generations in Brazil and Portugal. J Clean Prod: 124947

Shah SAA, Longsheng C, Solangi YA, Ahmad M, Ali S (2020) Energy trilemma based prioritization of waste-to-energy technologies: implications for post-COVID-19 green economic recovery in Pakistan. J Clean Prod: 124729

Sharma HB, Vanapalli KR, Cheela VRS, Ranjan VP, Jaglan AK, Dubey B, Goel S, Bhattacharya J (2020) Challenges, opportunities, and innovations for effective solid waste management during and post COVID-19 pandemic. Resour Conserv Recycl 162:105052

Shen M, Song B, Zeng G, Zhang Y, Huang W, Wen X, Tang W (2020) Are biodegradable plastics a promising solution to solve the global plastic pollution? Environ Pollut:114469

Silva ALP, Prata JC, Walker TR, Duarte AC, Ouyang W, Barcelò D, Rocha-Santos T (2020) Increased plastic pollution due to COVID19 pandemic: challenges and recommendations. Chem Eng J: 126683

Sim K, Chua HC, Vieta E, Fernandez G (2020) The anatomy of panic buying related to the current COVID-19 pandemic. Psychiatry Res 288:113015

Singh SH (2020) Lockdown helps bring back plastic bags. The Hindu. https://www.thehindu.com/news/national/telangana/lockdownhelps-bring-back-plastic-bags/article31381638.ece. Accessed 13 July 2020

Singh N, Tang Y, Ogunseitan OA (2020a) Environmentally sustainable management of used personal protective equipment. Environ Sci Technol 54:8500-8502

Singh N, Tang Y, Zhang Z, Zheng C (2020b) COVID-19 waste management: effective and successful measures in Wuhan. China Resources, Conservation, and Recycling 163:105071
SNPA (2020) CoViD-19 emergency: SNPA indications on waste management. Sistema Nazionale per la Protezione dell'Ambiente (ITALY). https://www.snpambiente.it/2020/03/24/emergenzacovid-19-indicazionisnpa-sulla-gestione-dei-rifiuti/. Accessed 5.17. 20

Sogancioglu M, Yel E, Ahmetli G (2017) Pyrolysis of waste high density polyethylene (HDPE) and low density polyethylene (LDPE) plastics and production of epoxy composites with their pyrolysis chars. J Clean Prod 165:369-381

Somani M, Srivastava AN, Gummadivalli SK, Sharma A (2020) Indirect implications of COVID-19 towards sustainable environment: an investigation in Indian context. Bioresource Technology Reports 11: 100491

Song W, Pan B, Kan H, Xu Y, Yi Z (2020) Evaluation of heat inactivation of virus contamination on medical mask. J Microbes Infections $15: 31-35$

Sousa AF et al (2015) Biobased polyesters and other polymers from 2, 5 furandicarboxylic acid: a tribute to furan excellency. Polym Chem 6: 5961-5983

Tabish M et al (2020) Approaches for prevention and environmental management of novel COVID-19. Environ Sci Pollut Res:1-11

Tenenbaum L (2020) The amount of plastic waste is surging because of the coronavirus pandemic Forbes URL: https://www.forbes.com/ sites/lauratenenbaum/2020/04/25/plastic-waste-during-the-time-ofcovid-19

Thakur V (2020) Framework for PESTEL dimensions of sustainable healthcare waste management: learnings from COVID-19 outbreak. J Clean Prod: 125562

Thakur V, Mangla SK, Tiwari B (2020) Managing healthcare waste for sustainable environmental development: a hybrid decision approach. Bus Strateg Environ

Tirkolaee EB, Abbasian P, Weber G-W (2020a) Sustainable fuzzy multitrip location-routing problem for medical waste management during the COVID-19 outbreak. Sci Total Environ: 143607

Tirkolaee EB, Mahdavi I, Esfahani MMS, Weber G-W (2020b) A robust green location-allocation-inventory problem to design an urban waste management system under uncertainty. Waste Manag 102: $340-350$

UN (2020) Waste Management during the COVID-19 Pandemic Available from: https://www.unenvironment.org/resources/report/ waste-management-during-covid-19-pandemic-response-recovery

UNEP (2020) BASEL:waste management an essential public service in the fight to beat COVID-19. . The United Nations Environment Programme (UNEP) and The Basel Convention. http://www.basel. int/Implementation/Public Awareness/PressReleases/ WastemanagementandCOVID19/tabid/8376/Default.aspx. Accessed 5.17.20

USEPA (2020) Recycling and sustainable management of food during the coronavirus (COVID-19) public health emergency. https://www. epa.gov/coronavirus/recycling-and-sustainablemanagement-foodduring-coronavirus-covid-19-public-health. 25 May 2020

Van Doremalen N et al (2020) Aerosol and surface stability of SARSCoV-2 as compared with SARS-CoV-1. N Engl J Med 382:1564 1567

Vanapalli KR, Sharma HB, Ranjan VP, Samal B, Bhattacharya J, Dubey BK, Goel S (2020) Challenges and strategies for effective plastic waste management during and post COVID-19 pandemic. Sci Total Environ 750:141514

Varbanov PS, Jia X, Lim JS (2020) Process assessment, integration and optimisation: the path towards cleaner production. J Clean Prod: 124602

Veronesi P, Leonelli C, Moscato U, Cappi A, Figurelli O (2005) Nonincineration microwave assisted sterilization of medical waste. $\mathrm{J}$ Microw Power Electromagn Energy 40:211-218

Vollmer I et al (2020) Beyond mechanical recycling: giving new life to plastic waste. Angew Chem Int Ed 59:15402-15423 
Voudrias EA (2016) Technology selection for infectious medical waste treatment using the analytic hierarchy process. J Air Waste Manage Assoc 66:663-672

Wang $J$ et al (2020a) Disinfection technology of hospital wastes and wastewater: suggestions for disinfection strategy during coronavirus disease 2019 (COVID-19) pandemic in China. Environ Pollut: 114665

Wang L, Wu W-M, Bolan NS, Tsang DC, Li Y, Qin M, Hou D (2020b) Environmental fate, toxicity and risk management strategies of nanoplastics in the environment: current status and future perspectives. J Hazard Mater 401:123415

WHO (2020) Water, sanitation, hygiene, and Waste Management For the COVID-19 virus: Interim guidance. https://apps.who.int/iris/ bitstream/handle/10665/331846/WHO-2019-nCoV-IPC WASH2020.3-eng.pdf. Accessed 4.30.20

WIEGO (2020) Informal worker demands during COVID-19 crisis. https://www.wiego.org/informal-workerdemands-during-covid-19crisis. 25 May 2020

Wilson DC et al (2015) Global waste management outlook. UNEP
Yao B-G, Wang Y-x, Ye X-Y, Zhang F, Peng Y-L (2019) Impact of structural features on dynamic breathing resistance of healthcare face mask. Sci Total Environ 689:743-753

Y in S, Rajarao R, Sahajwalla V (2018) Thermal transformation of metallized plastic packaging waste into value-added $\mathrm{Al} / \mathrm{Al} 3 \mathrm{C} 4 / \mathrm{AlN}$ resources. ACS Sustain Chem Eng 7:1723-1733

Yunus AP, Masago Y, Hijioka Y (2020) COVID-19 and surface water quality: improved lake water quality during the lockdown. Sci Total Environ: 139012

Zambrano-Monserrate MA, Ruano MA, Sanchez-Alcalde L (2020) Indirect effects of COVID-19 on the environment. Sci Total Environ: 138813

Zhang Y et al (2018) Effect of the aerosol-phase state on secondary organic aerosol formation from the reactive uptake of isoprenederived epoxydiols (IEPOX). Environ Sci Technol Lett 5:167-174

Zhang H, Tang W, Chen Y, Yin W (2020) Disinfection threatens aquatic ecosystems. Science 368:146-147

Zhao B, O'Connor D, Zhang J, Peng T, Shen Z, Tsang DC, Hou D (2018) Effect of pyrolysis temperature, heating rate, and residence time on rapeseed stem derived biochar. J Clean Prod 174:977-987 